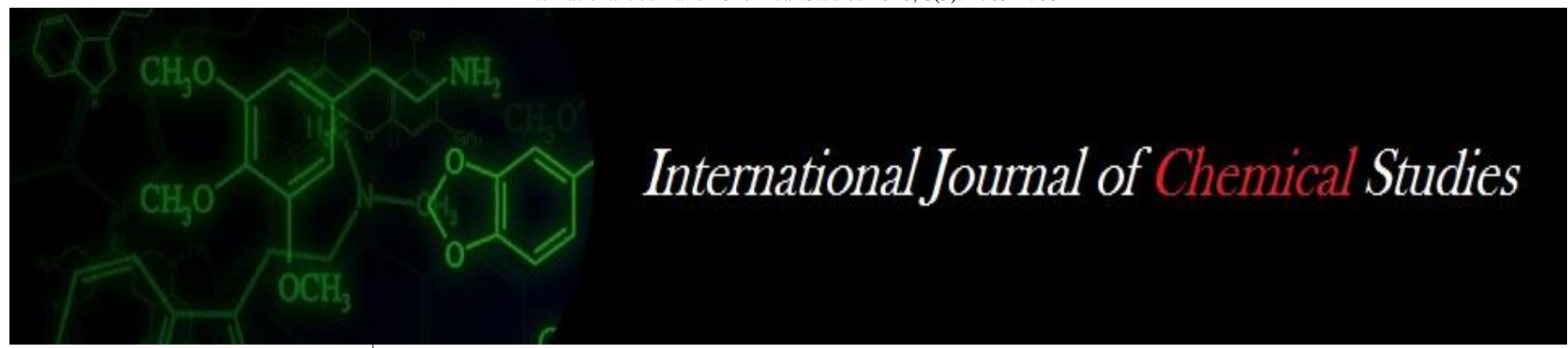

P-ISSN: 2349-8528

E-ISSN: 2321-4902

www.chemijournal.com

IJCS 2020; 8(5): 1705-1708

(C) 2020 IJCS

Received: 05-06-2020

Accepted: 10-08-2020

Swarnali Duary

Department of Agronomy,

Bidhan Chandra Krishi

Vidyalaya, Mohanpur, Nadia,

West-Bengal, India
Corresponding Author: Swarnali Duary

Department of Agronomy, Bidhan Chandra Krishi

Vidyalaya, Mohanpur, Nadia, West-Bengal, India

\section{Seed priming: A comprehensive approach to alter the biotic and abiotic stresses of field crops}

\author{
Swarnali Duary \\ DOI: https://doi.org/10.22271/chemi.2020.v8.i5w.10545
}

\begin{abstract}
Seed may be considered as the most important and vital factor which is structurally a fertilized matured ovule. Seed priming, the process of controlled hydration of seeds up to a level that permits pregerminative metabolic activity of seed to proceed, but prevents actual emergence of the radicle. Seed priming is a simple, safe and effective technology which can be easily adopted by resource-poor farmers and moreover it has the potential to benefit such farmers in a numbers of other ways. Commercialisation of the seed priming technology has been expanded rapidly now a day. Seed priming is a popular, low cost and commercially used technique. For combating biotic and abiotic stress in crops and alleviating the detrimental effects of stress without much affecting its fitness seed priming emerges as a promising technology. Extensive study was done by various workers using different seed priming techniques viz. hydro-priming, halo-priming, osmo-priming, matrix priming, hormonal priming, nutri-priming, biopriming etc.
\end{abstract}

Keywords: Seed priming, biotic stress, abiotic stress

\section{Introduction}

In modern agriculture, advance technologies are being deployed for breaking yield barriers and enhancing crop productivity (Prasad et al., 2016) ${ }^{[25]}$. Abiotic and biotic stress severely affects the crops growth and development at different stages of growth cycle. This unwanted and unfortunate event ultimately leads to crop failure or yield loss, thus makes crop production expensive or can lead resource poor farmers committing suicide. However, plants get higher level of fitness or readiness to overcome the harmful effects of stress situation due to priming. The primed plants are generally able to respond more rapidly and more effectively for stress protection. Being unavoidable, abiotic stresses have major negative impact on crop production worldwide. These stresses such as inadequate and inconsistent rainfall, alkalinity, salinity, extreme temperature, and some other factors aren't only limiting crop yield but also seem to be inevitably worsening.

\section{Seed priming}

Seed priming indicates control hydration of seed up to a certain level that permits the pregerminative metabolic activity to proceed but it prevents the normal emergence of the radicle (Hemender et al., 2018) ${ }^{[9]}$. Seeds are dried to the initial moisture content after soaking. The seed is taken through a biochemical process within that activates the initial stages of germination. The priming process regulates the seed's temperature and moisture content, bringing the seed closer to the point of germination and then carefully dried to stop germination for planting. When the primed seeds are planted, we are shortening the germination time and improving the uniformity of the crop upon emergence.

\section{Physiological and biochemical changes induced by seed priming}

When the primed seeds are sown, the imbibition phase and lag phase of water absorption are shortened. The swelling of the embryo inside the primed seed speeded up germination by facilitating water absorption. Seed priming stimulates the pre-germination metabolic processes and makes the seed ready for radicle protrusion (Pawar et al., 2018) ${ }^{[23]}$. 


\section{Advantages of seed priming}

1) Seed priming helps to overcome induced dormancy 2) It reduces the time necessary for germination and for subsequent emergence to occur. 3) Seed priming improves the stand uniformity, thus maintained plant population and enhance uniformity at the time of harvest (Debbarma et al., 2017) ${ }^{[6]} 4$ ) It also extends the range of temperature for seed germination. 5) Priming enables seeds of many species to germinate and emerge at supra-optimal temperatures (Das et al., 2015) ${ }^{[5]}$. 6) It also eliminates or greatly reduces the amount of seed-borne pathogen (Basra et al., 2002) [3] 7) Priming enhances the crop yield. 8) Germination inhibitors from seeds are also leached out from seed by seed priming. 9) And finally it also improves the resistance towards different kind of biotic and abiotic stresses.

Debbarma et al. (2017) ${ }^{[6]}$ represent the yield benefit obtained through different method of seed priming of several field crops for the different soaking hours;

Table 1: Soaking time and the percentage of benefits observed due to priming

\begin{tabular}{|c|c|c|}
\hline Crop & Soaking hour & $\begin{array}{c}\text { Maximum yield benefits } \\
\text { obtained (\%) over control }\end{array}$ \\
\hline Wheat & 12 & 37 \\
\hline Barley & 12 & 40 \\
\hline Aerobic Rice & $12-18$ & 70 \\
\hline Maize & $12-18$ & 22 \\
\hline Sorghum & 10 & 31 \\
\hline Pearl millet & 10 & 56 \\
\hline Chick pea & 8 & 50 \\
\hline Mung bean & 8 & 206 \\
\hline Finger millet & 8 & 15 \\
\hline
\end{tabular}

Source: Debbarma et al., $2017^{[6]}$

\section{Abiotic and biotic stresses faced by crop plants}

Crop plants encounter a complex set of abiotic and biotic stresses very frequently. Among them insect, pathogen, pest, weed (biotic stress), drought, water logging, salinity, alkalinity (abiotic stress).

\section{Different types of priming Hydro-priming}

Hydro-priming involves soaking of seeds in water before sowing (Pill and Necker, 2001) ${ }^{[24]}$ which allows the seed to imbibe water and go through the first phase of germination in which pre-germination metabolic activities are started while the latter two phases of germination are inhibited. The technology of hydro priming is very simple and cost effective also. Alias et al. (2018) ${ }^{[1]}$ concluded that Kailan, Menang and Hybrid dwarf Pak Choy variety of Brassica shows less mean germination time in hydro-priming than control plot.

\section{Halo-priming}

Halo priming refers to soaking of seeds in solution of inorganic salts like $\mathrm{NaCl}, \mathrm{KNO}_{3}, \mathrm{CaCl}_{2}, \mathrm{CaSO}_{4}$, etc. (Nawaz et al., 2013) ${ }^{[21]}$. Priming of seed with $\mathrm{NaCl}$ or $\mathrm{KCl}$ is helpful in removing the harmful effects of salts (Iqbal et al., 2006) ${ }^{[10]}$. Halogenation treatment is also done with different halogen like $\mathrm{Cl}, \mathrm{Br}, \mathrm{Fe}, \mathrm{F}$ and vapour is used for this purpose. Priming with $2.5 \% \mathrm{KNO}_{3}$ and Priming with $2.0 \% \mathrm{KCl}$ result more seed yield, straw yield and test weight over control and also required less days to mature control (Kumar et al., 2016) [16].

\section{Osmo-priming}

In osmo-priming seeds are treated with $\mathrm{Na}_{2} \mathrm{HPO}_{4}$ or $\mathrm{K}_{2} \mathrm{HPO}_{4}$ which act as an antioxidant into the seed. Seeds are soaked for a certain period in solutions of sugar, poly-ethylene glycol (PEG), glycerol or sorbitol followed by air drying under shade before sowing (Nawaz et al., 2013) ${ }^{[21]}$. Priming with $1.0 \%$ $\mathrm{KH}_{2} \mathrm{PO}_{4}$ result more seed yield, straw yield and test weight over control and also require less days to mature over control (Kumar et al., 2016) ${ }^{[16]}$. With comparing primed and control seeds, it is clear that seed priming enhanced seed germination speed and by the way hydro priming treatment is more suitable than osmo-priming treatments and the adverse effect of germination synchrony in osmo-priming treatments may be related to the decreased water uptake in osmo-priming treatments (Yucel, 2012) ${ }^{[31]}$.

\section{Matrix-priming}

Matrix priming refers to incubation of seeds in a solid insoluble matrix (vermiculite, diatomaceous earth) with a limited amount of water (McDonald, 2000) ${ }^{[20]}$. The different soil matrix carriers are micro celle, celite, press mud, jute mat, peat soil, compost. Solid matrix priming (SMP) in which water uptake by seeds is controlled and developed as an alternative method of osmo-priming because of high cost of osmotic agents and technical problems with aeration (Lutts et al., 2016) ${ }^{[17]}$. During solid matrix priming, seeds are mixed and incubated with wet solid water carrier for a certain period and then seeds are separated from matrix, rinsed, and backdried. Vermiculite, peat moss, charcoal, sand, clay, and some commercially offered substrate such as celie or micro cell are generally used solid carries which are applied in solid matrix priming. Soil matrix priming utilizes the chemical and physical characteristics of a solid material to control the water uptake of seeds (Jisha et al., 2013) ${ }^{[12]}$.

\section{Hormonal priming}

Hormonal priming is the pre seed treatment with different hormones i.e. abscisic acid, auxins, gibberellins, kinetin, ethylene, polyamines, and salicylic acid (SA) (Lutts et al., 2016) ${ }^{[17]}$ etc., which promote the growth and development of the seedlings (Sing et al., 2015). Kousar et al. (2018) [15] reported that the test weight $(36.60 \mathrm{~g})$ and yield (137.66 $\mathrm{g} /$ plant) is less in control plot than the salicylic acid treated plot of wheat and days to maturity also less in treated plot than control.

\section{Bio-priming}

Bio-priming involves seed imbibition together with bacterial inoculation of seed and some bacteria used as bio control agents are able to colonize rhizosphere and support plant in both direct and indirect way after germination stage. Some fungal antagonists used in bio-priming are 1) Trichoderma hamatum 2) Trichoderma hamatum 3) Trichoderma harzianum 4) Trichoderma viridae and common bacterial antagonists used are 1) Bacillus subtilis 2) Pseudomonas fluroscence 3) Serratia polymuthica 4) Pseudomonas aeruginosa 
Table 2: Role of Bio-priming in abiotic stress tolerance

\begin{tabular}{|c|c|c|c|c|}
\hline $\begin{array}{c}\text { Strains under } \\
\text { study }\end{array}$ & Crop & Role in stress tolerance & Plant growth promoting activities & Reference \\
\hline $\begin{array}{c}\text { Bacillus } \\
\text { pumilus }\end{array}$ & Potato & $\begin{array}{c}\text { Salinity, drought, heavy metal } \\
\text { stress tolerance }\end{array}$ & $\begin{array}{c}\text { Increase in plant height, No. of leaves plant }{ }^{-1}, \text { No. of } \\
\text { tubers plant }{ }^{-1} \text {, tuber yield plant }\end{array}$ & $\begin{array}{c}\text { Gururani } \text { et al. } \\
(2012)\end{array}$ \\
\hline Bacillus cereus & $\begin{array}{c}\text { Rice, Mungbean, } \\
\text { Chickpea }\end{array}$ & Salinity tolerance & $\begin{array}{c}\text { Salinity tolerance Increase in seedling height, number and } \\
\text { length of leaves, root and shoot biomass }\end{array}$ & $\begin{array}{c}\text { Chakraborty } \text { et al. } \\
(2011)\end{array}$ \\
\hline
\end{tabular}

Source: Mahmood et al., $2016^{[18]}$

Table 3: Role of Bio-priming in biotic stress tolerance

\begin{tabular}{|c|c|c|c|}
\hline Strains under study & Crop & Role in stress tolerance & Reference \\
\hline Tichoderma harzianum & Maize & Fusarium verticillioides and F. fumonisins tolerance & Nayaka et al. (2010) \\
\hline Pseudomonas fluorescens & Sunflower & Alternaria blight tolerance & Rao et al. (2009) \\
\hline Clonostachys rosea & Carrot & Alternaria dauci and A. radicina tolerance & Jensen et al. (2004) \\
\hline Pseudomonas fluorescens & Pearl millet & Downy mildew tolerance & Shetty et al. (2004) \\
\hline Pseudomonas fluorescens & Sweet corn & Damping-off tolerance & Mathre et al. (1991) \\
\hline
\end{tabular}

Source: Mahmood et al., $2016^{[18]}$

\section{Nano-priming}

Nano-priming is the priming of seed with nanoparticles (NPs) such as zinc oxide, iron oxide, titanium dioxide, silver nano particles etc. (Pawar et al., 2018) ${ }^{[23]}$. Due to nanoscale NPs over bulk it enhanced germination might be due to its nano size which allows them to penetrate through the seed coat easily and provide better absorption and utilization by seeds.

\section{Nutri-priming}

Nutri-priming refers to the priming of seed with a solution of mineral nutrients instead of soaking in simple water which combines the positive effects of seed priming with an improved nutrient supply. Some mineral nutrients like potassium, zinc, magnesium etc., are very critical for improved performance of crop plants under environmental stress conditions. The idea of nutri-priming is to obtain nutritional effect together with biochemical advantages of priming to improve seed quality, germination parameters, and seedling establishment (Farooq et al., 2012) ${ }^{[18]}$. Favourable effect on growth and nutrient status of cotton seedling under saline conditions was reported by K-priming (Shaheen et al., 2015) ${ }^{[27]}$.

\section{Chemical Priming}

Chemical priming means priming the seed with several chemicals which can promote seed performance under stress condition. It is help the plants to acquire resistance against abiotic stress by antioxidant production and other protective properties of several natural or synthetic compounds such as salicylic acid, ascorbic acid, ethanol, selenium, $\mathrm{CuSO}_{4}$, $\mathrm{ZnSO}_{4}, \mathrm{KH}_{2} \mathrm{PO}_{4}$, choline, and chitosan, etc., (Hemender et al., 2018) [9]. Numerous studies indicate positive impact of chemical priming with various priming agents in a wide range of environmental conditions [Anosheh et al. (2011) Khaliq et al. (2015)] [2, 3]. Fercha et al. (2014) ${ }^{[7]}$ concluded, priming with ascorbate counteracts the negative effects of salinity stress by changes in abundance of proteins involved in metabolism, protein destination, and storage.

\section{A few research reviews}

In pigeon pea seed priming with $\mathrm{CaCl}_{2}$ or $\mathrm{KNO}_{3}$ improved in proteins, free amino acid and soluble sugars under salt stress (Jyotsna and Srivastava, 1998) ${ }^{[13]}$. Priming with $\mathrm{NaCl}$ and $\mathrm{KCl}$ was helpful in removing the deleterious effects of salts (Iqbal et al., 2006) ${ }^{[10]}$. Prasad et al. (2016) ${ }^{[25]}$ reported studied the effect of nano scale zinc oxide $(\mathrm{ZnO})$ and chelated bulk zinc sulphate $\left(\mathrm{ZnSO}_{4}\right)$ on peanut seeds. It was observed that $1000 \mathrm{ppm}$ concentration of nano scale $\mathrm{ZnO}$ improved growth as compared to chelated bulk zinc sulphate by promoting seed germination, seedling vigour, earlier adaptability, growth, flowering, chlorophyll content, root shoot length and pod yield per plant, however, higher concentration of $2000 \mathrm{ppm}$ had negative effect on growth. Thiruppathi et al. (2018) ${ }^{[30]}$ concluded that seed priming with different agent such as $\mathrm{KCl}, \mathrm{KH}_{2} \mathrm{PO}_{4}, \mathrm{CaCl}_{2}$ and $\mathrm{ZnSO}_{4}$, water helps to increase the germination percentage, germination index, root length, shoot length than the control plot.

\section{Demerits of seed priming}

1) The primed seeds are not suitable for long period storing 2) The shelf-life of seed may reduce after priming 3 ) The primed seeds must be sown as soon as possible to get the benefits thus delay in sowing due to any abnormal situation may hamper the benefits 4) There may be uneven hydration and non-uniform germination 5) Depending on species, seed character, the ambient temperature and humidity at storage, the primed seed remains viable up to one year 6) If the primed seeds are stored in hot and humid conditions, it will lose its viability much more quickly

\section{Conclusion}

Seed priming is perhaps the best solution of germination related problems especially when crops are grown under unfavourable conditions. Seed priming emerges as a promising technology for combating biotic and abiotic stress in crops and alleviating the detrimental effects of stress without much affecting its fitness. There is a need to standardize suitable priming methods in different crops to combat biotic and abiotic stress in a sustainable manner. For improving the livelihoods of the farmers, solutions must be found through simple and effective means. Fortunately, such solutions are available, among which seed priming is one of the important and effective measure to establish the crop successfully.

\section{References}

1. Alias NSB, Billa L, Muhammad A, Singh A. Priming and temperature effects on germination and early seedling growth of some Brassica spp. Acta Horticulturae. 2018; 1225:407-414.

2. Anosheh HP, Sadeghi H, Emam Y. Chemical priming with urea and $\mathrm{KNO}_{3}$ enhances maize hybrids (Zea mays L.) seed viability under abiotic stress. Journal of Crop Science and Biotechnology. 2011; 14:289-295. 
3. Basra SMA, Zia MN, Mehmood T, Afzal I, Khaliq A. Comparison of different invigoration techniques in wheat (Triticum aestivum L.) seeds. Pakistan Journal of Arid Agriculture. 2002; 5:11-16.

4. Chakraborty U, Roy S, Chakraborty AP, Dey P, Chakraborty B. Plant growth promotion and amelioration of salinity stress in crop plants by a salt-tolerant bacterium. Recent Research in Science and Technology. 2011; 3:61-70.

5. Das A, Boruah R, Sharma SM, Pegu J. Seed priming -An effective method for crop production. International Journal Forestry \& Crop Improvement. 2015; 6(1):83-86.

6. Debbarma M, Das P. Priming of Seed: Enhancing Growth and Development. International Journal Current Microbiology and Applied Science. 2017; 6(12):23902396.

7. Fercha A, Capriotti AL, Caruso G, Cavaliere C, Samperi $\mathrm{R}$, Stampachiacchiere $\mathrm{S}$ et al. Comparative analysis of metabolic proteome variation in ascorbate-primed and unprimed wheat seeds during germination under salt stress. Journal of Proteomics. 2014; 108:238-25.

8. Gururani MA, Upadhyaya CP, Baskar V. Plant growthpromoting rhizobacteria enhance abiotic stress tolerance in Solanum tuberosum through inducing changes in the expression of ROS-scavenging enzymes and improved photosynthetic performance. Journal Plant Growth Regulation. 2012; 32(2):45-58.

9. Hemender VS, Mor, Sharma S, Jitender, Bhuker A. Seed Priming: A simple technique to mitigate salinity stress during germination and field emergence. production system. In: Proceedings of the national conference on innovative technological interventions for doubling farmers' income, 2018, 64p.

10. Iqbal M, Ashraf M, Jamil A, Rehmaan S. Does seed priming induce changes in the level of some endogenous plant hormones in hexaploid wheat plant under salt stress? Journal International Plant Biology. 2006; 481:8189.

11. Jensen B, Knudsen IMB, Madsen M. Biopriming of infected carrot seed with antagonist, Clonostachys rosea, selected for control of seed borne Alternaria spp. Phytopathology. 2004; 94(5):51-60.

12. Jisha K, Vijayakumari K, Puthur JT. Seed priming for abiotic stress tolerance: an overview. Acta Physiologiae Plantarum. 2013; 35:1381-1396.

13. Jyotsna V, Srivastva AK. Physiological basis of salt stress resistance in pigeon pea (Cajanus cajan L.)-11. Pre-sowing seed soaking treatment in regulating early seeding metabolism during seed germination. Plant Physiology and Biochemistry. 1998; 25:89-94.

14. Khaliq A, Aslam F, Matloob A, Hussain S, Geng M, Wahid A et al. Seed priming with selenium: consequences for emergence, seedling growth, and biochemical attributes of rice. Biological Trace Element Research. 2015; 166:236-244.

15. Kousar R, Qureshi R, Jalal-ud-din M, Munir and Shabbir G. Salicylic acid mediated heat stress tolerance in selected bread wheat genotypes of Pakistan. Pakistan Journal of Botany. 2018; 50(6):2141-3146.

16. Kumar R, Dhiman KC, Sharma JK, Sharma J. Effect of seed priming on seed yield and yield components of wheat (Triticum aestivum L.) under irrigated and rainfed conditions. Himachal Journal of Agricultural Research. 2016; 2(2):155-161.
17. Lutts S, Benincasa P, Wojtyla L, Kubala S, Pace R, Lechowska K, Quinet M, Garnczarska M. Seed Priming: New Comprehensive Approaches for an Old Empirical Technique. New Challenges in Seed Biology - Basic and Translational Research Driving Seed Technology, 2016, 1-49.

18. Mahmood A, Turgay O, Farooq M, Hayat R. Seed biopriming with plant growth promoting rhizobacteria: a review. FEMS Microbiology Ecology. 2016; 92(8):1-14.

19. Mathre DE, Miller JB, Callan NW. Field performance of sweet corn seed bio-primed and coated with Pseudomonas fluorescens. Horticulture Science. 1991; 26(1):16-35.

20. McDonald MB. Seed Priming. In: Seed Technology and its Biological Basis, Black M, Bewley JD. (Eds.). Shefield Academic Press, Shefield, UK, 2000; 287-325.

21. Nawaz J, Hussain M, Jabbar A, Nadeem AG, Sajid M, Subtain M et al. Seed priming a technique. International Journal of Agriculture and Crop Sciences. 2013; 6(20):1373-1381.

22. Nayaka SC, Niranjana SR, Shankar ACU. Seed biopriming with novel strain of Trichoderma harzianum for the control of toxigenic Fusarium verticillioides and fumonisins in maize. Arch Phytopathology. 2010; 43(2):64-82.

23. Pawar VA, Laware SL. Seed priming: A critical review. International journal of Scientific Research in Biological Science. 2018; 5(5):94-101.

24. Pill WG, Necker AD. The effects of seed treatments on germination and establishment of Kentucky bluegrass Poa pratensis L. Seed Science and Technology. 2001; 29:65-72.

25. Prasad SR, Kamble UR, Sripathy KV, Udaya Bhaskar K, Singh DP. Seed bio-priming for biotic and abiotic stress management. In: Singh DP, Singh HB, Prabha R (eds) Microbial inoc-ulants in sustainable agricultural productivity. research perspectives. Springer, New Delhi. 2016; 1:211-228.

26. Rao MS, Ramachandran N, Sowmya DS, Ratnamma K, Chaya MK, Manoj Kumar R. Biological control of nematode induced disease complex in certain vegetable crops. In: Proceedings of the Abstracts of International Conference on Horticulture, Bangalore, India, 2009, $213 p$.

27. Shaheen HL, Iqbala M, Azeema M, Shahbazb M, Shehzadia M. K-priming positively modulates growth and nutrient status of salt-stressed cotton (Gossypium hirsutum) seedlings. Archives of Agronomy and Soil Science. 2015; 62(6):759-768.

28. Shetty NP, Shetty HS, Raj SN. Proline-an inducer of resistance against pearl millet downy mildew disease caused by Sclerospora graminicola. Phytoparasitica. 2004; 32:52-37.

29. Singh H, Jassal RK, Kang JS, Sandhu SS, Kang H, Grewal K. Seed priming techniques in field crops - A review. Agricultural Review. 2015; 36(4):251-264.

30. Thiruppathi M, Kavitha R, Thanunathan K. Seed priming techniques for drought tolerance and its effect on growth of hybrid castor. Innovations in Agriculture. 2018; 1(1):13-15.

31. Yucel DO. The effect of different priming treatments and germination temperatures on germination performance of lentil (Lens culinaris medik) seeds. Journal of Agricultural and Biological Science. 2012; 7(12):125142. 